\title{
MADRES, MILITANTES Y ESPOSAS EN JAMÁS EL FUEGO NUNCA DE DIAMELA ELTIT Y LIBRETA DE FAMILIA DE PÍA GONZÁLEZ
}

\author{
Mothers, militants and wives in Diamela Eltit's Jamás el fuego nunca and Pía \\ González's Libreta de familia
}

\section{RESUMEN}

Este artículo discute las políticas de la memoria asociadas a los grupos anti-Pinochet y el rol de la mujer en estos discursos en la novela Jamás el fuego nunca (2007) de Diamela Eltit y Libreta de familia (2008) de Pía González. Específicamente, este estudio demostrará cómo ambas novelas cuestionan la imagen de la mujer producidas y perpetuadas en el espacio público por los grupos disidentes a la dictadura militar en Chile. Para lograr este objetivo, se discutirá cómo ambas novelas se alejan de técnicas narrativas y estéticas típicamente asociadas al realismo social para revelar la construcción de la militancia femenina, la familia y la maternidad como experiencias moldeadas por normas sociomasculinas. En última instancia, este artículo propone que ambos textos al re-imaginar las prácticas de la memoria de mujeres asociadas a los grupos guerrilleros o grupos disidentes de inspiración cristiana logran dar voz a sujetos cuyas experiencias han sido ignoradas, marginadas o cooptadas por discursos oficiales del pasado traumático en función de agendas políticas en el Chile post-dictadura.

\section{UNIVERSUM}

Revista de Humanidades y Ciencias Sociales

\section{GUSTAVO CARVAJAL}

Profesor asistente, Universidad Finis Terrae, Santiago, Chile.

Correo electrónico:

gcarvajal@uft.cl

ORCID: 0000-0002-5283-2672

ResearchGate:

Scholar.google: Academia.edu:

Palabras claves: Memoria; Género; Militancia, Maternidad, Dictadura.

Artículo recibido el 5 de octubre, 2019. Aceptado el 12 de abril, 2020.

DOI: http://dx.doi.org/10.4067/S0718-23762020000100288

Web: http://universum.utalca.cl | ISSN: 0716-498X - 0718-2376 


\begin{abstract}
This article discusses the politics of memory associated with the antiPinochet movements and the role of women in such discourses in Diamela Eltit's novel Jamás el fuego nunca (2007) and Pía González’s Libreta de familia (2008). In particular, this study will demonstrate how these novels challenge the image of women that collective discourses of the traumatic past produce and perpetuate in the public space. In order to do so, this article will discuss how both texts discard an aesthetic and narrative strategies typically associated with social realism to expose the construction of female militancy, the family and motherhood as experiences shaped by a sociomasculine logic. Ultimately, this study claims both novels by re-imagining the memory practices of women politically affiliated with urban guerrilla groups or dissident movements of Christian inspiration bear witness to the voices of individuals whose experiences have been ignored, marginalized or co-opted by official narratives in the aftermath of violence due to political agendas in post-dictatorship Chile.
\end{abstract}

Keywords: Memory, Gender, Militancy, Motherhood, Dictatorship.

Este artículo analizará la representación del pasado traumático reciente en Chile desde una perspectiva femenina de izquierda en las novelas Jamás el fuego nunca (2007) de Diamela Eltit y Libreta de familia (2008) de Pía González. Ambas novelas discuten críticamente las prácticas de formación de la identidad que afectaron a las mujeres en los movimientos anti-Pinochet, al concentrarse en las memorias de una antigua militante de izquierda revolucionaria (Jamás el fuego nunca) y la viuda de un activista social y político (Libreta de familia). En la novela de Eltit, una mujer recuerda su participación en un movimiento armado durante la dictadura y las consecuencias personales y colectivas de la militancia política radicalizada dentro de la izquierda en el Chile post-dictadura. La novela de González cuenta la historia de Laura y su esposo Nicolás, un joven activista asociado 
a los grupos de oposición en la izquierda cristiana. Veinte años después de la muerte de Nicolás, Laura recuerda el pasado a través de una serie de correos electrónicos que intercambia con una antigua amiga en donde discutirán cómo ella postergó su activismo para proteger su matrimonio y educar a dos hijas. La situación de las dos protagonistas de estas novelas y sus memorias muestran cómo las prácticas de la construcción de la identidad dentro de estos grupos de oposición han moldeado interpretaciones del pasado traumático luego de la violencia dictatorial. En ambos textos, la construcción de la mujer como militantes de izquierda radicalizadas, esposas o madres se vuelve una fuente de tensión entre los discursos de la memoria de los movimientos antiPinochet y los recuerdos personales de estas mujeres del Chile dictatorial. Así, a través del uso de estrategias narrativas que se alejan de una estética realista y denunciante, ambas novelas critican los discursos dominantes y las imágenes de género patriarcales movilizadas por estos grupos de oposición para narrar la lucha heroica, la derrota política y la violencia dictatorial en el Chile postdictadura.

Para lograr los objetivos antes descritos, este artículo se dividirá en tres secciones. Primero, se discute la producción de novelas chilenas de la dictadura desde la perspectiva de autores que representan el periodo a través de personajes que se afilian políticamente a la izquierda chilena. Esta sección busca situar el trabajo de Eltit y González dentro de un tipo particular de ficción post-golpe y post-dictadura y que puede ser descrita en términos generales como comprometida con la memoria de la izquierda derrotada. Las siguientes dos secciones articulan un análisis comparativo de las novelas, poniendo especial atención a sus estrategias narrativas que sirven para cuestionar las imágenes asociadas a las mujeres y movilizadas en las narrativas de los movimientos anti-Pinochet. La segunda sección discute la idea de militancia y los roles de género asociados a las mujeres en estos grupos disidentes. Esta sección demostrará que la renuncia a estrategias realistas y a un tono denunciante ayuda a ambos textos a desmantelar las políticas de representación de género de estos grupos. La última sección traslada la discusión hacia la maternidad como experiencia común de ambas protagonistas. Esta sección propone 
que ambas novelas pueden ser leídas también como textos que descartan la imagen tradicional de las madres de la izquierda denunciando y lamentando en el espacio público la desaparición de sus hijos. En la novela de Eltit, este proceso es parte de un esfuerzo mayor por despolitizar la maternidad a través de la memoria para mostrar algunos aspectos opresivos de la militancia de izquierda radical para las mujeres. En el caso de González, la representación deliberadamente estereotipada de la madre revela las estructuras machistas dentro de los movimientos anti-Pinochet de inspiración cristiana.

\section{LA NOVELA CHILENA, LA IZQUIERDA Y LA DICTADURA}

En su estudio sobre la novela chilena de la dictadura publicada entre los años 1977 y 2010, Mario Lillo (2013) identifica tres formas de representación del golpe de Estado y sus consecuencias para la identidad nacional chilena. En primer lugar, tenemos un grupo de novelas que proponen una memoria abarcadora de los traumas colectivos e individuales derivados del régimen dictatorial. Para este grupo de escritores, es el deber de la novela post-golpe denunciar el horror de la violencia política. En el otro extremo, Lillo identifica un grupo de novelas que ignora la representación del Chile en dictadura o la memoria del golpe de Estado. Para Lillo, las razones de esta decisión varían desde el deseo de ciertos autores de evitar el conflicto o peligro personal hasta la necesidad de negar la realidad de la violencia política ocurriendo en el país. El tercer grupo de obras muestra un compromiso menos radical con la memorialización literaria de la dictadura. Desde el retorno de la democracia, este grupo de textos aluden de manera indirecta al trauma político nacional. Son textos, opina Lillo, que optan por no satisfacer las demandas de los actores sociales interesados en recuperar la memoria histórica de la nación (Lillo 1145).

Desde mediados de los años 90, este sentido de obligación con la memoria de los caídos y derrotados inflamó el debate académico respecto de la necesidad de una novela socio-histórica sobre la dictadura que fuera capaz de representar el periodo y sus traumas (Kohut y Morales Saravia). 
Naturalmente, el regreso de la democracia moldeó el contexto cultural chileno para la práctica de la literatura. Como señalaba Carlos Franz a Verónica Cortínez en el contexto del Chile democrático:

[...] se levantaba el mandamiento histórico y entrábamos en un periodo de libertad creativa, en donde podíamos evitar hacernos cargo de dos cosas: la literatura de anuncio... y también dejar atrás la literatura de denuncia. Ni anuncio ni denuncia. (239)

A pesar del predominio de las representaciones literarias indirectas del pasado traumático, este tema desde la perspectiva de los "derrotados" también es detectable en la narrativa post-dictatorial. Principalmente desarrollada por escritores como Francisco Rivas, José Román, Gregory Cohen, Marco Antonio de la Parra, Ramón Díaz Eterovic, Darío Oses, Radomiro Spotorno, Carlos Tromben y Guillermo Rodríguez, los “derrotados” desarrollan un acercamiento distintivo a la representación del pasado. Uno de los elementos que los unen es su afiliación política. En términos generacionales, estos escritores son los herederos de los cambios sociales implementados en Chile por los sucesivos gobiernos asociados al Frente Popular desde la década del 30 del siglo pasado. Dehecho, muchos de estos escritores comparten la experiencia de haber recibido su formación intelectual en instituciones públicas de educación, pluralistas y seculares que florecieron en las décadas del 50 y 60 en Chile como el Instituto Nacional y la Universidad de Chile. Sus obras literarias son, por lo tanto, no solo críticas del golpe de Estado y la dictadura, sino también evidencian una nostalgia por un pasado frente-populista y admiración por aquellos escritores del periodo (escritores realista-sociales tales como Nicómedes Guzmán, Manuel Rojas o José Santos González Vera). Para Cristián Opazo (2009), este tipo de representación del trauma político es principalmente "historicista" y se vuelve al mismo tiempo otra patología asociada a la memoria colectiva de la izquierda: el duelo y nostalgia por un periodo perdido de justicia social y cambios culturales (109). De modo similar, Jaime Collyer señaló alguno de los obstáculos de los escritores chilenos cuando ideologías políticas intentaron informar la práctica literaria y su tratamiento del pasado en el Chile democrático: 
La conclusión es, pues, demoledora: la izquierda y la derecha unida jamás serán vencidas. Ambas - los nuevos "proges" [sic] y los fundamentalistas conservadores de siempre - buscan imponer sus procedimientos y contenidos a lo estético, ambas quieren un mensaje enaltecedor, ambas prohíben determinados hechos o subproductos estéticos antes de que ellos sucedan. (183)

En términos de estrategias narrativas, este grupo de autores afiliados a la izquierda se nutre de la novela social que florece en Chile en la década de los 30 y 40. Para Cedomil Goic (1972), este tipo de novela produjo historias para precipitar un cuestionamiento al sistema de clases en el país, desarrollando un discurso político cargado de exaltación de las utopías políticas frentepopulistas. De esta generación de autores, emerge la visión de la literatura como un instrumento que contribuye a la lucha socio-política en el país (217). La influencia de estos autores y producciones es vista en esta corriente narrativa post-dictatorial. Este punto es confirmado por Ramón Díaz Eterovic en una entrevista para Alejandro Lavquen (2007), declarando que sus novelas principalmente se nutren de dos fuentes preocupadas con el tratamiento y representación de temas sociales y políticos: la novela negra americana y la novela social chilena de los años 30 (Lavquen, 2007).

Una perspectiva nostálgica y predominantemente masculina, entonces, caracteriza a este grupo de novelas de la dictadura afiliado a la izquierda. En consecuencia, la atención académica se ha centrado en la producción narrativa o poética de voces masculinas. Dos estudios ayudan a ilustrar este punto. En el trabajo de Eugenia Brito (1994), solo la producción narrativa de una autora es examinada (Diamela Eltit) y el trabajo poético de Carmen Berenguer y Carla Grandi (111-142; 165-182). Similar desbalance se observa en el estudio de Verónica Cortínez anteriormente mencionado que considera el trabajo de cuatro autoras (Diamela Eltit, Elena Castedo, Marcela Serrano y Pía Barros) y nueve autores. La consecuencia de esto es que se perpetúa una perspectiva masculina del trauma político reciente, perspectiva que enfatiza como principales problemas de la época la lucha de clases y la opresión dictatorial. Así, las experiencias de las mujeres dentro de estos grupos afiliados a la izquierda 
y anti-Pinochet tienden a ser desplazadas en los discursos colectivos que también movilizan una retórica de resistencia heroica en contra de la injusticia social y represión política. Eltit y González cuestionan estas perspectivas predominantemente masculinas que narran el pasado. Ya sea al criticar las estrategias discursivas de la izquierda o parodiar la estética literaria cultivada por los escritores afiliados a la izquierda, ambos textos facilitan la emergencia de las voces de mujeres militantes o activistas. Esto es logrado, veremos a continuación, al representar a las mujeres militantes como intentando escapar del patriarcalismo existente dentro de los movimientos anti-Pinochet.

\section{FORMANDO MILITANTES Y ESPOSAS}

Jamás el fuego nunca se desarrolla en una pequeña habitación ocupada por una pareja de militantes revolucionarios. A pesar de que la dictadura ha terminado, la pareja sigue en clandestinidad, alienados de la sociedad chilena neoliberal. En esta precaria habitación, la pareja se ve obligada a sobrevivir soportando las restricciones de su vida en aislamiento. La tensa relación de la pareja surge a través de las discusiones referidas a temas políticos, militantes y, en particular, a la muerte del pequeño hijo de la mujer que constantemente recuerda. La novela finaliza cuando ella, después de una noche de insomnio y malestar, se prepara para ir a trabajar, aún atormentada por la muerte de su hijo y reconociendo que su situación no puede ser peor.

La mayoría de la novela explora la interioridad de la mujer (su ánimo, pensamientos y sentimientos). Digresiones, asociaciones impredecibles, conexiones y delirios dan forma a la narración, priorizando las memorias de la mujer por sobre el desarrollo de una trama o eventos externos a su experiencia. En este sentido, la novela no está interesada en representar el pasado como un periodo de conflicto nacional y trauma histórico. El lector solo puede adivinar el escenario de la novela y no se dan referencias reales a eventos, incidentes o figuras de los grupos guerrilleros operando durante la dictadura. La novela entonces puede ser leída como un intento de cuestionar las convenciones narrativas del tipo de novela realista que discutimos anteriormente al usar un 
registro y tono casi alucinatorio para recordar el pasado desde la perspectiva femenina. Para llevar adelante este cuestionamiento, Eltit se concentra en dos dimensiones de la formación de militantes femeninas en los movimientos guerrilleros: sus identidades y sus cuerpos.

Desde el comienzo de la novela, Jamás el fuego nunca es articulada como el monólogo perturbado de una mujer consumida. La mujer obsesivamente recuerda y medita sobre la condición en ruinas de los cuerpos sociales e individuales, la maternidad y la militancia política. Al avanzar la novela, un estado pesadillezco moldea la voz y los recuerdos de la mujer, haciendo difícil para el lector determinar si la pareja vive o no. Por ejemplo, la descripción de la habitación que comparten se asemeja a la de un nicho mortuorio o mausoleo, y a lo largo de la novela la mujer observa y dialoga con los espectros de camaradas muertos que parecen invadir la habitación. Estas estrategias narrativas producen una imagen de la mujer caracterizada por una subjetividad rota. A través de este registro alucinatorio, la novela se opone a narraciones convencionales del pasado, que se concentran en explorar las causas y consecuencias socio-políticas del régimen dictatorial. De hecho, la voz de la mujer, que a menudo divaga hacia la memoria, ayuda a exponer sus luchas en contra de una ideología que le demanda reformular su identidad en función de normas siempre socio-masculinas.

En este sentido, Eltit explora la identidad como una categoría "asaltada" para las mujeres integrantes de los movimientos revolucionarios. En los movimientos urbanos guerrilleros anti-Pinochet, la construcción de nuevas identidades (identidades falsas) era parte de las tácticas de seguridad para hombres y mujeres. Sin embargo, Eltit exhibe las memorias de las mujeres de tales tácticas como símbolos de los procesos de reformulación de las identidades guiados por los hombres en el contexto de la clandestinidad y la militancia radicalizada. Los efectos de tales prácticas son opresivos para la mujer y su difuso "yo" en la novela: 
Continuamos, en gran medida, clandestinos, nos situamos afuera, radicalmente. No contamos con nombres civiles, seguimos prendidos a nuestra última chapa, ya nos acostumbramos o nos posesionamos, no lo sé. Pero si alguien dijera mi nombre civil, no voltearía la cara. (32)

A pesar del hecho de que la narración está estructurada a partir de la perspectiva de la mujer, sus declaraciones en la tercera persona plural nos dan una indicación clara de una ideología que demanda el repudio del "yo" para abrazar un colectivo "nosotros" (masculino). Nelly Richard (2010) ha observado la misma práctica lingüística cargada de significado ideológico al analizar testimonios de mujeres militantes. Comentando la autobiografía de Gladys Marín, Richard nota que la ex secretaria general del Partido Comunista chileno y miembro del Frente Patriótico Manuel Rodríguez solo puede hablar en plural (86). Como la misma Marín declara en una entrevista: "nosotros tenemos esas manías en las formas de expresar que, por ejemplo, nos hacen hablar de nosotros y nunca decir yo" (Richard y Eltit 135). Estas particularidades, para Richard, le dan al discurso de Marín y sus memorias un tono épico y noble acorde a su militancia revolucionaria en el contexto de un movimiento colectivo de acción anti-dictatorial.

Así, el abrazo de un "nosotros" masculino es reforzado en la novela a través de la eliminación de toda marca de individualidad de los personajes en la novela. Jamás el fuego nunca se estructura en torno a personajes femeninos y masculinos sin nombres. Significativamente, la única persona preocupada por su estatus como individuo sin nombre es la mujer. Su condición anónima muestra el proceso radical de reformulación de la identidad a la que se sometió como militante. De hecho, el hombre sigue a cargo de esta última célula revolucionaria que sobrevive e integran ellos. Sin embargo, la mujer rápidamente cuestiona lo que inicialmente parece ser una constante del relato. Es decir, la mujer transita entre marcas lingüísticas que exponen su subjetividad ideologizada (y su disolución en lo colectivo), y aquellos momentos en donde lucha por recuperar su "yo" en el presente. A pesar de que no sabemos su nombre en la novela, la mujer recuerda y revela los nombres de antiguos 
camaradas en abierto cuestionamiento a la lógica militante y el control del hombre, mezclando sus recuerdos con imágenes fantasmagóricas:

La dirección del partido formando una fila deprimente arriba de ese escenario imposible, aglutinados, indiferenciados, parecían simples militantes, nunca dirigentes, eso no, en cambio tú brillabas en el canto y brillaba el gordo López y Ximena y quizás incluso yo brillaba (el gordo López, justo desde una esquina de la pieza ahora niega toda esa escena con la cabeza, pálido, furioso, pero ya no me importa, tan pálido que está el gordo mientras Ximena me habla, insiste en mi asesinato, acostada al lado mío, me lo susurra al oído, en secreto). (108)

El proceso de recordar el pasado parte con la enunciación de nombres de los desaparecidos o asesinados de su antigua célula, que a su vez son presencias fantasmales que pueblan el relato. Nombrar a sus camaradas es también una forma de recuperar su "yo" del "nosotros" colectivo de izquierda. El uso de una imaginería alucinatoria y un registro fantástico hacen este proceso de recuperación del "yo" posible. Esta estrategia y tono se oponen al discurso épico y grandioso de carácter historicista con el que la izquierda derrotada tiende a representar el pasado traumático (y que identificamos se asocia a un tipo de novela post-golpe y post-dictadura).

La memoria de esta mujer también se refiere a las operaciones disciplinarias ejercidas sobre el cuerpo como para de una formación militante siguiendo un modelo sociomasculino. Pilar Calveiro, ex militante Montonera y académica argentina, recuerda la importancia de tales prácticas "generizadoras" del cuerpo femenino en el contexto de la guerrilla urbana durante la última dictadura Argentina:

[E]n la militarización [de los grupos políticos] predomina una lógica masculina y las prácticas son de carácter principalmente masculino. Tienen que ver más con la fortaleza del cuerpo, el uso de la violencia y las aptitudes socialmente más desarrolladas por los varones. (Lazzara, Olivera-Williams y Szurmuk 343)

No es accidental que la mujer en Jamás el fuego nunca recuerde momentos en los cuales su cuerpo es controlado en la lógica del militante revolucionario masculino. Su cuerpo se transforma en un sitio de conflicto en donde el poder es ejercido: 
Tú la odiabas, la grasa, el cuerpo graso y su brillo. Un cuerpo redondeado por capas de una grasa licuada que producía esa languidez que postergaba la agilidad, esa agilidad que tú pedías para la célula y que si no se ajustaba a tu deseo, debíamos rehacer con otros cuerpos disponibles, hambrientos y energéticos. (21)

Esta cita muestra dos operaciones importantes para la mujer. Primero, la importancia de recuperar estos momentos personales para ella, alejándose de las demandas propias de una mirada militante. Segundo, ubica al cuerpo como un lugar en donde los efectos del poder pueden verse en operación. Por supuesto, me refiero acá a las ideas de Foucault acerca del cuerpo como uno de los sitios privilegiados de lucha en relación a operaciones de poder. Sus ideas son útiles en el contexto de la reformulación de la identidad femenina en un ambiente de militancia, ya que Foucault concibe a los individuos no como sujetos estables, sino que como entidades que "existen" debido a operaciones de poder ejercidas sobre ellas: "it is already one of the prime effects of power that certain bodies, certain gestures, certain discourses, certain desires, come to be identified and constituted as individuals" (98). La representación del cuerpo en la novela evoca estas ideas de Foucault:

Podíamos sólo consumir lo necesario para nuestros fines. No correspondía, así lo dijiste, entregarse a la comida, hacer de ella una sede que terminaba por ocultar el impacto del hambre. El hambre, lo sé, tenía para ti una función. El hambre, lo pregonaste, era un estado que profundizaba el rigor y nos permitía un trabajo concreto y sostenido. (21)

Esta escena muestra cómo la construcción de la militancia se implementa a través de operaciones de poder sobre el cuerpo. Junto a memorias de un poder opresor que tortura, mata y hace desaparecer cuerpos, la mujer visibiliza instancias en donde operaciones biológicas (nutrición) y la sublimación de deseos y emociones son el resultado de otras operaciones opresivas ejercidas sobre su cuerpo militante. Además, lo que es más significativo de estos recuerdos es el hecho de que estas son prácticas del pasado que la mujer recuerda pero que aún siguen operando en el presente. De hecho, como la misma mujer declara, su precario cuerpo todavía experimenta las operaciones disciplinarias dictadas por el hombre. Quizás el ejemplo más claro de esto ocurre en relación con un vestido del cual la mujer habla: 
Recuerdo que salí a la calle en un acto completamente desatinado, quebrando cualquier lógica de seguridad. [...] Y de pronto experimenté el impacto ante ese vestido que, aunque me negué a reconocerlo, ocupó enteramente mi deseo y se apoderó de mi mente en oleadas anhelantes y secretas. [...] Su tela, su caída, su diseño y la urgente, enloquecida necesidad de comprar el vestido, vestirme, exhibirlo en mí, comerme el vestido, devorarlo enteramente, gastar en la tela, en el diseño, en la caída, entregarme sin pudor, ajena a cualquier átomo de culpa, a un placer bacanal y absoluto con la exterioridad, la superficie más dañina en la que podía recalar mi cuerpo. Renunciar a la renuncia que hicimos en los primeros años en que nos refugiamos de una vez y para siempre detrás de un consistente desprecio. (210)

María Inés Lagos argumenta que este episodio demuestra el poder total del hombre sobre la mujer: "como se observa en el episodio del vestido, la mujer desea el vestido y al mismo tiempo siente el veredicto del compañero que la inhibe, y no lo compra" (101). Lagos entiende esta escena como una derrota para la mujer, ya que el veredicto del hombre dicta la decisión de la mujer. La memoria del vestido muestra los discursos y códigos entre los que la mujer y su cuerpo están atrapados: una idea masculinizada de la militancia política en el pasado y a femineidad sexualizada (la sensualidad del vestido) explotada en el presente neoliberal chileno. Así, la forma en que la memoria funciona y es ejercida por la subjetividad resquebrajada de esta mujer militante rompe con la tendencia de narrar el trauma de los "derrotados" como una experiencia social y política colectiva. El pasaje anterior descarta el retrato oficial de la guerrilla, la revolución social y la resistencia heroica en contra la opresión dictatorial. En su lugar, la memoria fragmentada y digresiva de la mujer se vuelve un medio para el repudio de un discurso ideológico radicalizado que en diversas circunstancias implicó el control disciplinario del cuerpo e identidad femeninas.

En el caso de Libreta de familia, los procesos de formación de la identidad también se concentran en la conciencia social y activismo bajo dictadura. Sin embargo, hay una diferencia crucial entre los textos en la diferente conceptualización y uso de la memoria. Mientras Eltit transforma la memoria en una herramienta útil para visibilizar y exponer prácticas opresivas de la militancia sobre la identidad femenina, González opta por atenuar el 
uso de la memoria para en su lugar satirizar la novela realista y a la clase social que por excelencia retrató este tipo de novela: la burguesía. A través de este procedimiento, la novela logra cuestionar representaciones oficiales del pasado y, en particular, la imagen de las mujeres afiliadas al activismo social de inspiración cristiana durante la dictadura. De hecho, la novela describe ambientes, espacios y caracteres de modo muy similar a un "cuadro de costumbres". La narración se concentra en los problemas cotidianos de Laura y Nicolás como una pareja de clase alta viviendo, por convicciones políticas, en un barrio proletario de Santiago.

Por supuesto, hay razones particulares que motivan el uso de González de estrategias de la novela realista para satirizar las convenciones de los discursos burgueses respecto del rol de la mujer en el espacio público. González hace explícita la conexión entre este tipo de novela, una clase social (la burguesía cercana a la Iglesia Católica) y la formación de la identidad femenina de su protagonista. En la novela, el activismo social de Laura es, en última instancia, una sátira de las inclinaciones de jóvenes de origen burgués "comprometidos" con los más pobres. Por ejemplo, su deseo de promover la justicia y el cambio social nunca se traducen en acciones concretas para lograr sus objetivos. Laura nunca realmente hace algún esfuerzo en esta dirección, a pesar de experimentar la dictadura desde la perspectiva de "los pobres". El único cambio real en su existencia ha sido precisamente la proletarización de su estilo de vida, ya que Nicolás no tiene un trabajo regular y la pareja lucha por sobrevivir. De hecho, cuando Laura conoce a sus "vecinos" (habitantes de una toma colindante a una casa que Nicolás arrendó para ellos), una hambrienta Laura felizmente acepta un plato de comida caliente de la olla común que sus vecinos han organizado (78). Irónicamente, Laura se vuelve la receptora de ayuda de aquellos que la pareja ha optado por "ayudar", experimentando la dictadura desde "los que sufren". A lo largo de la novela, ella recibe en múltiples ocasiones más la ayuda de sus vecinos. Pero cuando la brutalidad de la dictadura literalmente llega a su patrio trasero (en donde se ubica la toma), la realidad de un allanamiento es tan abrumante que Laura es incapaz de ayudar a sus vecinos. Camina hasta la pared colindante con la 
toma y permanece agachada e inmóvil escuchando los gritos, llantos y golpes. El muro medianero la protege del horror y luego del allanamiento Laura se arrastra a la casa, llora desconsoladamente y espera el regreso de Nicolás para contarle lo sucedido (86).

Además, la caracterización continua del narrador de la ingenuidad y docilidad de Laura solo acentúa la representación satírica de la burguesía cercana a la Iglesia Católica y sus valores en la oposición al régimen militar. El narrador nos cuenta cómo Laura percibe a Nicolás como su "salvador", casi como un joven príncipe "que llegó en el momento justo a ofrecerle una vida nueva" y por esta razón "jamás dudaría de su amor" (21). Debido a esto, rara vez expresa sus dudas y preocupaciones respecto de las largas ausencias de Nicolás del hogar mientras ella permanece encerrada cuidado de sus dos pequeñas hijas. Laura también difícilmente cuestiona cualquier decisión tomada por Nicolás respecto de su vida como una pareja comprometida con los más pobres. Esto tiene consecuencias para las inclinaciones activistas de Laura. En realidad, el activismo de Laura es más vicario que una experiencia real. Por ejemplo, luego de haber tenido a su primera hija, Laura habla con Nicolás para retomar sus estudios universitarios. El narrador explora los pensamientos de Laura respecto de este deseo. Rápidamente, nos damos cuenta de que el narrador usa la siguiente escena para burlarse de cómo, en la mente de Laura, el regreso a la universidad es suficiente para satisfacer su activismo social cristiano-burgués:

Habían transcurrido dos meses desde su retorno [...] No piense el lector que era cuestión fácil. Ni siquiera tan divertida como pareció en esa vuelta a casa de donde Macarena. Pero valió la pena [...] Era estimulante recorrer nuevamente los pasillos con rayados subversivos (tímidos, pero elocuentes), las salas llenas de humo, el olor a la biblioteca, la fuente de soda de la esquina donde se juntaban a tomar cerveza. (153)

Una experiencia vicaria, el narrador nos informa, es todo lo que Laura necesita y obtiene de su regreso a la universidad, transitando por sus corredores repletos de grafitis políticos inofensivos. Laura siente es parte de los movimientos anti-Pinochet a través de esta "proximidad" a ciertos 
signos de disidencia. Sin embargo, tales señas de protesta se ubican dentro de la seguridad que entrega una universidad privada a la que Nicolás le ha permitido asistir solo por un par de días a la semana. Su "disidencia" no es practicada en partes más peligrosas de la ciudad. La imagen de unas salas de clases repletas de humo de cigarrillos, la biblioteca y un bar universitario refuerzan la representación satírica del narrador del activismo social de origen cristiano-burgués y las experiencias de las mujeres en estos movimientos. El "activismo" universitario de Laura se asocia a situaciones de inacción (humo de cigarrillos), al silencio (biblioteca) y al escapismo (bar universitario), y que despliega para satisfacer sus frustraciones de clase media y su culpa.

En otra escena posterior, el narrador describe un momento en donde el activismo de Laura es ejercido, pero nuevamente, se acentúa una representación que deja en claro no tiene un impacto real o influencia en espacios más allá de la seguridad de su hogar con Nicolás. Luego de asistir a la universidad por un tiempo, Laura le cuenta a Nicolás acerca de uno de sus profesores, un colaborador y defensor del régimen militar. En una clase, él despliega una defensa del Gobierno. Durante su vehemente defensa, Laura hace preguntas críticas al profesor, lo que lo motiva a seguir defendiendo y opinando del general Pinochet:

Laura llegó a casa atorada por contarle a Nicolás el episodio. Era de esperar que él se enojara. La retó, que cómo se le ocurría abrir la boca, que tenía que ser invisible, que habíamos quedado en eso, etcétera y etcétera, pero finalmente no se pudo contener al ver a Laura con gestos dramáticos imitar al profe, y lloraron juntos de risa, se entiende. (154)

Con esta escena, el narrador satiriza dos convenciones asociadas a la clase media conservadora que condicionan el actuar de la mujer (su activismo) y su identidad en dictadura. Una de ellas es la idea de que las mujeres, cuando se les permite abandonar temporalmente el hogar, deben ser invisibles y permanecer en silencio en el espacio público. La segunda es la imagen de Laura imitando a un colaborador del régimen para entretener a Nicolás. En otras palabras, un esposo solo cede a las inquietudes políticas de su mujer (que se revela en la cita por su explosión de risa), cuando es inofensiva y es desplegada en el hogar. 
Más adelante en la novela, el rol de género principal de Laura queda plenamente establecido. Hacia el final del relato, los movimientos antiPinochet entran literalmente a su casa. Esto ocurre debido a una fiesta de cumpleaños que Laura organiza para Nicolás. La fiesta es un intento de Laura de escapar de su rol de esposa y madre que ha cumplido sin reclamos. Laura abre las puertas de su casa a los amigos de Nicolás en un intento por subvertir la construcción de género que le corresponde dentro de estos movimientos cercanos a la Iglesia Católica. Sin embargo, el narrador rápidamente hace explícito el fracaso de esta estrategia, enfatizando la separación entre Laura y los invitados. Durante la velada, los invitados invaden cada rincón de la casa, dejando a Laura confinada en la cocina, cocinando para ellos. Además, cuando la comida está lista y ella lo anuncia, el narrador nos informa, "su voz fue ignorada" (201). La descripción de la fiesta que hace el narrador no hace más que acentuar la diferencia entre Laura y este grupo:

[Laura] buscó un lugar junto a Nicolás. Pero era imposible [...] al otro costado Pedro gesticulaba con vehemencia discutiendo con Osvaldo. Tendría que haber hecho una extraña maniobra para encontrar lugar [...] Lo que habría puesto todas las miradas en lo ridículo de su actitud. Ella era la dueña de casa, era la mujer de Nicolás ¿tenía que gritar por su lugar? Estoy fuera, fue el primer pensamiento que ensombreció el semblante de Laura. (201-202)

La deseada oportunidad de Laura de unirse al grupo nunca se materializa durante la fiesta. Predeciblemente, los invitados "se fueron [...] casi todos al mismo tiempo" (208). Nicolás, por supuesto, durante la fiesta no nota la frustración de Laura y la ignora durante toda la velada. De hecho, luego de una intensa discusión finalizada la fiesta, Nicolás se va a la cama en silencio y al otro día se despierta al alba para reunirse con su amigo Osvaldo y otros activistas. Laura, el narrador destaca, se queda en casa a "ordenar los restos de la fiesta" (210). Su matrimonio, tal como es descrito por el narrador, enfatiza las monolíticas convenciones de su clase social asociadas a la construcción del rol de la mujer, aun cuando algunos de sus miembros participan activamente en la organización de resistencias en contra de un régimen que ubica una imagen similar de la mujer al centro de su "reconstrucción" del país. 


\section{LA CONSTRUCCIÓN DE UNA MADRE}

La maternidad es una fuente importante de preocupación para ambas protagonistas en las novelas. En Jamás el fuego nunca, la mujer constantemente recuerda la muerte de su hijo bajo las restricciones impuestas por la clandestinidad. Este evento y su recurrencia en la novela son significativos, ya que el trauma de una fallida maternidad lleva los discursos militantes a su crisis. En Libreta de familia, la maternidad no es recordada, sino referida por dos voces: la voz de Laura y la del narrador omnisciente. Estas voces resaltan una imagen paródica de la madre. Esta imagen es importante, ya que la parodia de la maternidad dentro de los grupos anti-Pinochet de inspiración cristiana se vuelve un medio para exponer su manipulación en narrativas oficiales del pasado traumático en Chile.

La intersección entre maternidad, política y los movimientos antidictatoriales en Latinoamérica ha producido imágenes muy poderosas de mujeres denunciando la desaparición de sus hijos y luchando por mantener su memoria viva. Los ejemplos más representativos de estos movimientos son las Madres de la Plaza de Mayo en Argentina y la Asociación de Familiares de Detenidos Desaparecidos (AFDD) en Chile. Muchos puntos en común presentan ambos movimientos: la imagen heroica de su lucha en tiempos de violencia política, la transformación individual de estas mujeres debido a su activismo público y su compromiso con la memoria de los desaparecidos. Pero también, hay una diferencia crucial entre ambos grupos precisamente en términos de maternidad. Diana Taylor ha argumentado en el caso argentino que el movimiento de las Madres de Plaza de Mayo comenzó precisamente cuando estas mujeres comenzaron a protestar en el espacio público como madres. Esto significó representar sus maternidades individuales en la esfera pública y denunciar la desaparición de sus hijos. La maternidad en público fue transformada, señala Taylor, en una identidad politizada. Para lograr esto, las Madres inicialmente modelaron su identidad siguiendo la imagen de la Virgen María como mater dolorosa (194). En contraste, el acercamiento a la memoria de las madres de la AFDD se vinculó más explícitamente a una raíz 
de militancia política. Estas mujeres no comenzaron a actuar en el espacio público como madres sino que como madres militantes. Así, lo maternal es subsumido por la militancia en las narrativas oficiales del pasado traumático producidas por la izquierda chilena militante. Entre estas dos construcciones de la maternidad asociadas a la militancia y pérdida de hijos, la madre en Eltit emerge como una voz que testimonia las consecuencias de experimentar una ambigua y extrema forma de maternidad en los movimientos anti-Pinochet. En este sentido, leemos la construcción de la madre en Jamás el fuego nunca en contraste con las imágenes asociadas a las Madres de Plaza de Mayo y de la AFDD en Chile.

A través de sus memorias de la maternidad, la mujer en Jamás el fuego nunca presenta una imagen altamente opresiva y en crisis de la militancia. Estas memorias sirven para agitar las imágenes tradicionales asociadas al heroísmo de aquellos militantes derrotados por el régimen. Los momentos que ella recuerda asociados a la agonía y muerte de su hijo siempre van unidos a recuerdos de la militancia en crisis y disolución. Por ejemplo, previo al primer recuerdo del niño, la mujer declara que el último grupo que integró ya estaba permeado por "un cansancio hostil que ya había invadido letalmente a nuestra célula" (43). Más adelante en la novela, luego de recordar a su hijo vivo y sano, la mujer le pregunta al hombre: "Pero ¿hubo triunfos?, te pregunto, ¿al menos una victoria?, ¿cuál célula fue exitosa o sana?, ¿en qué espacio conseguimos contribuir?" (83). Pero quizás el ejemplo más evidente de su crítica se observa antes de recordar detalladamente la agonía del niño hacia la mitad de la novela (104). Justo antes de este momento, la mujer conecta este recuerdo con otros momentos de aniquilación de diferentes grupos y a las acciones de un camarada en particular:

[...] el petiso Maureira, el petiso que colaboraba a diestra y siniestra con los grupos reformistas, el mismo petiso que después asomaría su rostro en la fotografía del diario y ambos cerramos los ojos conmocionados o aterrados de ver a Maureira sin su chapa, reconvertido en Javier Montes, sí, legal, orgulloso de exhibir su nombre en el periódico, el petiso que se cambió de lado, en el momento justo, cuando todavía era posible y debilitó nuestra célula sin dudar para conseguir su permanencia en una historia que, lo vemos, lo vivimos, lo padecemos, no iba a llegar a ninguna parte. (104) 
Esta estrategia se repetirá a lo largo de toda la novela. Así, la posibilidad de un balance entre militancia y maternidad es rápidamente descartada en la novela. Al mismo tiempo, surge una imagen más matizada de la madre. Esta ambigüedad le da a la novela su poder disruptivo respecto de los modelos de género dentro de la militancia de izquierda radicalizada. La mujer afirma:

\begin{abstract}
Somos, así lo pactamos, una célula. [...] Lo hicimos después que se hubo de consumar la muerte [...] porque era una muerte que nos competía y nos desgarraba. No lo llevamos al hospital, no parecía posible. Mis súplicas, lo sé, eran una mera retórica, una forma de disculpa o de evasión. No podíamos acudir con su cuerpo mermado y agónico, acezante y agónico, macilento y agónico, amado y agónico, al hospital, porque si lo hacíamos, si trasladábamos su agonía, si la desplazábamos de la cama, poníamos en riesgo la totalidad de las células porque caería nuestra célula y una estela destructiva iría exterminando el amenazado, disminuido campo militante. (66)
\end{abstract}

La contribución de la mujer a la muerte de su hijo es evidente acá. A pesar de los esfuerzos de la pareja por cuidar al bebé durante su agonía, su muerte para proteger otras células clandestinas destruye el mito de la madre protectora. Jamás el fuego nunca no ofrece, entonces, interpretaciones y narrativas definitivas sobre la militancia de las mujeres y su maternidad en dicho contexto. Al contrario, la novela enfatiza la imposibilidad de acceder a una explicación definitiva sobre el pasado traumático y el rol de las mujeres en los movimientos guerrilleros (y en contra de los discursos totalizantes producidos por estos grupos militantes). La mujer recuerda la opresión de su cuerpo, la construcción de su identidad militante desde una norma sociomasculina, pero al mismo tiempo se muestra como parte y perpetuadora de dichas prácticas. No es completamente una víctima de la opresión militante ni tampoco una victimaria. Esta indefinición en la novela es productiva como estrategia para cuestionar los discursos/narrativas suturantes del pasado traumático para los derrotados. El reconocimiento de sus plegarias como mera retórica, una forma de exculpación o evasión, abre la figura de la madre y su construcción en la lógica militante a otras interpretaciones. Cuando esta mujer recuerda, entonces, imágenes tales como la mater dolorosa no son completamente abrazadas. También, el discurso de la memoria de las madres en la AFDD enraizado en 
lo militante tampoco es posible. La pregunta por el "dónde están" los hijos muertos y desaparecidos de la dictadura se vuelve redundante para la mujer, ya que ella sabe exactamente el destino de su hijo muerto en clandestinidad.

En Libreta de familia, la representación paródica de la madre como el núcleo de la familia nacional reconciliada permite a González cuestionar las identidades de género asociadas a la mujer en discursos oficiales de la memoria en Chile. El principal discurso cuestionado es el movilizado durante el proceso re-democratizador liderado por dos presidentes demócratas cristianos y la fuerte influencia de la Iglesia Católica. Como Martín Hopenhayn resalta respecto de la temprana transición:

En el centro mismo de la vida política asistimos a un fenómeno que hace veinte años nos habría parecido alarmante y que hoy incorporamos como un dato: la fuerte influencia de la Iglesia y de sus valores en el discurso del Estado y de los partidos. [...] El Estado Laico, ideal encarnado en décadas precedentes, pierde sus contornos. La pastoral y las encíclicas parecieran ser más que opiniones de la institución eclesial: normatividad que el gobierno y la ciudadanía deben recoger e interiorizar. (139-140)

Una idea conservadora de la familia y la imagen venerada de la madre como el centro de esta unidad social fueron constantemente movilizadas en el espacio público durante la transición a la democracia para confirmar normas culturales y objetivos políticos alineados con tales valores. Este punto lo confirma Nelly Richard, particularmente en relación a discursos que involucran a la familia y al rol de la mujer en dicha institución. Richard afirma: “el gobierno de la Transición democrática necesitó hiperbolizar el discurso de la Familia para fundar nuevos vínculos de estabilidad comunitaria que se encargaran de naturalizar el reencuentro del país consigo mismo" luego de la violencia dictatorial (200-201).

La Laura que conocemos en el Chile democrático es, en consecuencia, el resultado de una construcción de la maternidad fuertemente influida por la Iglesia Católica: madre abnegada que renuncia a su propia identidad e intereses en el espacio público para cuidar a sus dos hijas en el espacio privado del hogar. Por esta razón, Laura aparece en los correos electrónicos que intercambia con su amiga de juventud (Macarena) como la encarnación 
de una imagen conservadora de lo materno, acorde a los nuevos tiempos democráticos en Chile. De hecho, en sus correos a Macarena no se menciona ningún otro aspecto de su vida que no tenga relación con sus dos hijas. El propio acto de recordar, Laura reconoce, ocurre solo cuando "los hijos [...] se van" (11). Laura en el presente es la madre definitiva, pura generalidad. Esto es reforzado por la importancia que tiene para Laura en sus correos la inminente boda de su hija Manuela, evento que constantemente menciona a su amiga en los correos. El hecho de que se celebrará una boda religiosa (105) solo confirma la perpetuación de una ideología conservadora de género que ha logrado transmitir a su hija en el presente democrático.

Además de esta imagen de Laura a través de sus correos electrónicos en el presente democrático como la madre definitiva, el narrador también moviliza otra representación paródica de su identidad transformada en una generalidad durante la década de los 80 en Chile. Esta imagen paródica puede ser entendida recurriendo al pensamiento de Simone de Beauvoir en su texto canónico, El segundo sexo (1949). El análisis de Beauvoir respecto de la mujer, la familia y la maternidad resuena claramente en la novela. Laura es una mujer de clase media atrapada en un matrimonio infeliz, vive una maternidad solitaria en su hogar y el jefe de hogar a menudo está ausente en el día a día. Todo esto es fuente de frustraciones para Laura, muy similares a las descritas por Beauvoir respecto de las mujeres de clase media en Europa en la década de los cuarenta y cincuenta del siglo pasado. La situación de la mujer chilena en el Chile dictatorial no es muy distinta a la experimentada por las mujeres que estudia Beauvoir. Como Julieta Kirkwood describe, la situación de la mujer en Chile en los años 80 (época en que se sitúa Libreta de familia) es precaria:

En Chile, el Movimiento Feminista es apenas emergente y no ha tenido aún el tiempo de teorizar, en el sentido de dar coherencia a los principios y problemas expuestos por las mujeres en su actividad práctica. Tampoco ha tenido el tiempo de elaborar estrategias en torno al problema de la autonomía, de la doble militancia, de la forma de insertarse en el campo político, de cómo iniciar una praxis pública. (180) 
En este contexto entonces, así es cómo el narrador describe la maternidad de Laura durante la misma época que describe Kirkwood en Chile:

Su papel de madre primeriza la hizo olvidarse del mundo exterior y respirar según el horario de Manuela. En la inexperiencia, se exigía una dedicación minuciosa, ocupando gran parte de las horas del día y de la noche [...] Dejó de lado cualquier distracción del exterior, y la casa del pasaje se convirtió en escuela de puericultura y en monasterio de voto de silencio. (122-123)

Acá vemos operando las mismas prácticas y consecuencias para la identidad femenina(cuandolamaternidad se desarrolla en uncontextopatriarcal) que Beauvoir describe en su texto. La maternidad, argumenta Beauvoir, toma control total de la vida de la mujer. Esto implica un impacto en sus relaciones con su esposo, su pasado, su ocupación y con sí misma. A menudo, esto transforma la maternidad en una carga para la mujer. La maternidad solo es gratificante para la mujer, Beauvoir propone, cuando la madre también puede activamente participar en la vida social, política y económica. El mito de la pertenencia exclusiva entre madre e hijo (que presupone la natural condición de la madre para el cuidado de los hijos) obstaculiza la introducción de la mujer en la vida pública (499-504). Estas son precisamente las circunstancias y efectos que el narrador describe para la maternidad de Laura. Pero, al describir abiertamente la maternidad de Laura en un tono humorístico (a través de asociaciones entre lo maternal, escuelas y monasterios), el narrador está subrayando el rol maternal como una categoría "escenificada" o "pre-escrita", un rol que Laura actúa no solo bajo la dictadura, sino también en democracia. De hecho, Laura no intenta liberarse ni siquiera luego de la muerte de Nicolás. La noción de actuar roles preestablecidos es clave en Libreta de familia, y es la forma de evidenciar la crítica a la construcción de Laura como la madre absoluta. La novela está llena de personajes que actúan roles pre-escritos. Por ejemplo, Nicolás es el revolucionario de origen burgués y su amigo sacerdote Osvaldo es el "cura-obrero" mártir que muere asesinado por el régimen. El narrador al hacer mofa de la maternidad enmarcada en los movimientos disidentes de inspiración cristiana hace explícita la construcción de su identidad como una categoría artificial. Esto es necesario, ya que la memoria oficial que Libreta 
de familia buscar debilitar (Chile como una familia reconciliada en torno a la mujer, la madre de la nación) produce tal imagen, y permanece como uno de los mecanismos que perpetúa la maternidad como mecanismo de control de la mujer en el Chile democrático.

En síntesis, ambas novelas representan a la mujer asociada a los grupos anti-Pinochet y el rol que cumplen en las narrativas oficiales del pasado traumático que dichos grupos promueven en el espacio público, pero solo para interrumpir su legitimidad y cuestionar su imagen en estos discursos. Para lograr esto, ambas novelas exploran estrategias narrativas que se alejan del realismo, ya que encuentran en estas herramientas una forma para desmantelar los discursos oficiales del pasado traumático que se han construido sobre normas típicamente sociomasculinas. De esta forma, ambos textos son exitosos al re-imaginar las prácticas de la memoria de mujeres militantes y disidentes, dando voz a sus experiencias sobre la militancia femenina, el activismo político y la maternidad. En conclusión, uno de los muchos aportes de ambas novelas puede situarse precisamente en la discusión de estas valiosas experiencias femeninas que han sido tradicionalmente ignoradas, silenciadas o co-optadas para cumplir un rol estratétigo en los discursos de la memoria y satisfacer agendas políticas sociomasculinas en el Chile post-dictadura.

\section{REFERENCIAS}

Beauvoir, Simone. The second sex. Ed. H. M. Parshley. Trad. H. M. Parshley. London: Jonathan Cape, 1956.

Brito, Eugenia, ed. Campos minados. Literatura post-golpe en Chile. Santiago: Cuarto Propio, 1994.

Collyer, Jaime. «Escribir en Chile hoy. La nueva censura.» Literatura chilena hoy. La dificil transición. Ed. Karl Kohut y José Morales Saravia. Frankfurt/Main \& Madrid: Vervuert Verlag \& Iberoamericana, 2002. 177-186. 
Cortínez, Verónica. «Entrevista colectiva.» Albricia. La novela chilena de fin de siglo. Ed. Verónica Cortínez. Santiago: Cuarto propio, 2000. 231262.

Eltit, Diamela. Jamás el fuego nunca. Santiago: Seix Barral, 2007.

Goic, Cedomil. Historia de la novela hispanoamericana. Valparaíso: Universitarias, 1972.

González, Pía. Libreta de familia. Santiago: Cuarto propio, 2008.

Gordon, C., ed. Power/Knowledge. Brighton: Harvester, 1980.

Hopenhayn, Martín. «Moral y secularización en el Chile finisecular: especulaciones para el debate.» ¿Hacia dónde va la sociedad chilena? Ed. Cecilia et al Montero. Santiago: Colección Estudios CIEPLAN, 1993. 136-145.

Kirkwood, Julieta. Ser politica en Chile. Santiago: Flacso, 1986.

Kohut, Karl y José Morales Saravia, Literatura chilena. La dificil transición. Frankfurt/Main \& Madrid: Vervuert Verlag \& Iberoamericana, 2002.

Lagos, María Inés. «Subjetividades corporalizadas: "Maldito amor" de Rosario Ferré y “Jamás el fuego nunca" de Diamela Eltit.» Nomadías (2009): 87-110.

Lavquen, Alejandro. «Díaz Eterovic: en la pista de la fama.» Punto Final. 7 de abril de 2007. 29 de agosto de 2019. < https://bit.ly/2YMPtxi>.

Lazzara, Michael J., María Rosa Olivera-Williams y Mónica Szurmuk. «Violencia, memoria, justicia: una entrevista a Pilar Calveiro.» $A$ Contracorriente (2013): 324-346.

Lillo, Mario. Silencio, Trauma y Esperanza: Novelas Chilenas de la Dictadura. Santiago: Ediciones UC, 2013.

Opazo, Cristián. «Anatomía de los hombres grises: reescrituras de la novela social en el Chile de postdictadura.» Acta Literaria 38 (2009): 91-109.

Richard, Nelly. Crítica de la memoria (1990-2010). Santiago: Ediciones UDP, 2010. . Residuos y metáforas. Santiago: Cuarto Propio, 1998. 
Richard, Nelly y Diamela Eltit. «Gladys Marín: un retrato.» Debates críticos en América Latina I. Ed. Nelly Richard. Santiago: Cuarto Propio, 2008. 129-139.

Taylor, Diana. Disappearing acts: spectacles of gender and nationalism in Argentina's "Dirty War". Durham \& London: Duke University Press, 1997. 